\title{
P08-05. Does increased expression of HLA-C allow better control of HIV-I viral load?
}

\author{
S Brackenridge*1, T Corrah ${ }^{1}$, E Haygreen ${ }^{2}$, K Lavender ${ }^{2}$, T Dong1, \\ N Goonetilleke ${ }^{1}$, P Borrow ${ }^{2}$ and A McMichael ${ }^{1}$
}

Address: ${ }^{1}$ Weatherall Institute of Molecular Medicine, University of Oxford, Oxford, UK and ${ }^{2}$ Jenner Institute, University of Oxford, Compton, UK

* Corresponding author

from AIDS Vaccine 2009

Paris, France. 19-22 October 2009

Published: 22 October 2009

Retrovirology 2009, 6(Suppl 3):PII3 doi:I0.I I86/I742-4690-6-S3-PII3

This abstract is available from: http://www.retrovirology.com/content/6/S3/PII3

(C) 2009 Brackenridge et al; licensee BioMed Central Ltd.

\section{Background}

A polymorphism 35 kb upstream of the HLA-C gene (the "-35 SNP") correlates with host control of HIV-1 in Caucasians: the minor allele (C) associates with lower set point viral loads than the major allele $(\mathrm{T})$. A link between viral load and HLA-C is suggested by linkage of the two SNP alleles with different HLA-C alleles, and by the fact that HLA-C is not down-regulated by nef.

\section{Methods}

We are investigating whether the -35 SNP correlates with the surface level of HLA-C using the antibody DT9, which recognises both HLA-C and HLA-E. The contribution of HLA-E to this staining is being assessed with the HLA-Especific antibody MEM-E/06, and saturation-binding experiments are being used to measure the relative levels of HLA-E and HLA-C. We are also investigating functional differences individuals homozygous for the protective (C/ C) and non-protective (T/T) -35 alleles.

\section{Results}

DT9 staining of lymphocytes is significantly lower for T/T subjects compared with $\mathrm{C} / \mathrm{C}$ subjects $(\mathrm{p}=0.046)$, but this is due to HLA-Cw7. Staining of T/T individuals who are homozygous for $\mathrm{Cw} 7$ is significantly lower than for both $\mathrm{C} / \mathrm{C}$ individuals $(\mathrm{p}=0.004)$ and $\mathrm{T} / \mathrm{T}$ individuals who do not have (or who are heterozygous for) Cw7 ( $p=0.007$ ). We see no difference in the frequency or magnitude of ex vivo T cell responses to HLA-C-restricted peptides between $\mathrm{C} / \mathrm{C}$ and $\mathrm{T} / \mathrm{T}$ HIV-infected subjects. Likewise, there is no difference in the ability of NK cells from $\mathrm{C} / \mathrm{C}$ and $\mathrm{T} / \mathrm{T}$ subjects to control the replication of HIV in vitro. T cell clones specific for HLA-C-restricted peptides are being generated to investigate if the efficiency of peptide presentation by antigen presenting cells correlates with the -35 SNP, and the interactions of NK cells with macrophages and dendritic cells are being addressed.

\section{Conclusion}

DT9 staining suggests that surface levels of HLA-C are only significantly lower for $\mathrm{T} / \mathrm{T}$ subjects who are homozygous for HLA-Cw7. 